\title{
VIEWPOINTS
}

\section{The 'Common Good' and Malaysia's Education System}

\author{
Zarina Nalla*
}

\section{What is the 'Common Good'?}

This Viewpoint is an attempt to understand the concept of the 'common good' and in light of this, assess how the Malaysian school system can best educate young minds to create and serve this ideal. As a concept, the 'common good' is often debated among commentators. It would be safe to say, however, that it may be understood in two ways: first, as a state of general welfare which occurs when society attains the greatest good for the greatest number of individuals, not shared equally in an arithmetic sense but according to people's needs and abilities. The second, and more important, aspect would be the procedural principles, set up by custodians of that society, to best ensure the growth and flourishing of every citizen.

The common good is by no means merely material, but also spiritual and its manifestations include the common happiness borne out of shared experiences from shared settings and the development of civic behaviour.

\section{What is the 'Common Good' in Relation to Education?}

The institutions of a society then become instruments of the common good. We can all agree that education is a key institution required to ensure the flourishing of every individual in our society.

Policy-makers in Malaysia need to grapple with the question of how the education system can cultivate and develop in our children a moral identity that will support the common good. Preparing them for a life in a multiethnic setting in which they are expected to empathise with the other and play their roles as good citizens of this nation is a noble goal of education. Hence, the issue of creating a moral identity as an agent of change becomes a pressing one.

* Zarina Nalla is a Consultant with IAIS Malaysia. 


\section{Malaysia's Social Reality}

Malaysia is not a 'nation-state' like Japan but a family of many ethnicities and religions. Each ethnic group is championing its own causes in almost all areas, among them economics, education, and religion. The prevailing political multi-party systems based on ethnicity or communalism makes the goal of Bangsa Malaysia (Malay for 'Malaysian nation', lit. 'Malaysian race'), in its truest or extreme sense, elusive, i.e. a Malaysian nation-state of citizens rather than a nation-state of ethnicities.

In reality, however, Malaysian leaders concur that assimilation is not desirable, because loyal citizens should not demand that an individual be made to choose between his or her identities, but rather be given space so as to accommodate them all. An individual may be a woman, a Chinese, a Muslim, and a mother all in one.

Some have suggested that it may be realistic to aim for a level at which ordinary citizens will claim to be Malaysians first, while being of Indian, Chinese, or Malay ethnicity coming second. Education is unarguably one of the most powerful tools a nation has to build its identity. Especially a young nation such as ours.

A local survey reveals that there is a clear correlation between age and mixing outside one's own ethnic group. Younger Malaysians find it difficult to relate to those who are different from them ethnically and hence reluctant to mix with other races. We can extrapolate from here that they obviously do not perceive themselves as Malaysians first. This has fragmented the Malaysian identity in terms of nationbuilding.

The ethnic divide - so apparent in this country - could be made less prominent if the notion of 'common citizenship' can be reinforced to our children during their impressionable years. Students could think of themselves as Malaysian rakyat (citizen) or warganegara (nationality) in order to create a national identity that will unite the community and galvanise its members to serve the 'common good' as opposed to the 'particular good'.

Hence the notion of the 'common good' is inextricably linked to the notion of unity as a community and the appreciation of others. The current Prime Minister, Najib Tun Razak, said that the government concept of 1Malaysia was a continuation of the agenda of nation-building and, for the country to progress, the people must achieve progress first, and this had to begin with the attitude of inter-racial acceptance which brought about strong unity. When unity had been achieved, then the process of national development would be smoother, he said.

\section{Shared Experience during Critical School Years}

The education system has not been instrumentalised effectively to unite the nation. In 2004, former Prime Minister Tun Abdullah Ahmad Badawi said that the government 
was concerned with the current poor level of ethnic integration and understanding where schools were becoming more 'mono-racial', with non-Malay enrolment in national schools growing smaller with time. According to his address to the 2004 Malaysian Education Summit, 93 per cent of the Malays attend national schools, 90 per cent of the Chinese attend Chinese vernacular schools, and 70 per cent of the Indians attend Tamil vernacular schools. Moreover, at the 13th Education Summit in 2009, the Deputy Secretary-General of the National Union of the Teaching Profession (NUTP) reiterated that despite the government's steps toward promoting national unity in national schools, the greatest obstacles are language barriers and ethnic polarisation. Hence at the primary level, where children are most impressionable, we have three 'mono-ethnic' streams!

Most young Malaysians spend the first six or even up to eleven formative years in an environment which is dominated by one race, language and culture. Our children are robbed of a shared experience, and the polarisation does not end there, it continues during the pre-university years and then to university periods, when non-bumiputeras ${ }^{1}$ generally attend private institutions of higher learning and the bumiputeras go to national universities. The school system is an important tool to nurture young minds, to imbibe moral values that we treasure in our society. Individuals construct moral knowledge and their sense of justice through early interaction.

In 2010, Sheikh Dr Ahmad Badr al-Din Hassoun, Grand Mufti of Syria and a known proponent of intercultural dialogue, addressed an audience at IAIS Malaysia and emphasised that children should be exposed to other cultures, ways of thinking, and histories, so that when a child leaves its 'safe space' or his original environment it will not be unfamiliar with others. In a way, the school is a child's 'first world' in which he or she is socialised and has the golden opportunity to experience interaction within a multicultural setting. As the Grand Mufti said, this prepares the child for young adulthood in the larger society.

\section{Recommendations}

Some have suggested multicultural education as a possible solution. It will help students understand and affirm their own cultural identities, while not allowing these boundaries to limit them in any way. By respecting and recognising the diverse cultures of their fellow citizens, it becomes possible to create a civic community that will work for the 'common good'. Others think that teaching history is important. Malaysia's Education Ministry recently announced that history will be compulsory for Sijil Pelajaran Malaysia which is equivalent to the ' $\mathrm{O}$ ' levels. There was debate as to what 'version' of history should be taught to the students. The most controversial path mooted was the call to abolish the segregated school system which many feel obstruct national unity. This provoked an outcry from several quarters. 
- Policy-makers who are cognisant of the sensitivities need to rise to the occasion and find a suitable compromise or solution that most can accept.

- Perhaps this shortcoming can be addressed by civil society, parents, the private sector, and other stakeholders who can assume the responsibility of bridging the different ethnic groups in the Malaysian polity.

- Research demonstrates that even weekly exposure of children in a teamwork setting to other students from different racial backgrounds will improve integration.

\section{Note}

1. In Malaysian parlance, the originally Sanskrit term bumiputera (lit. 'son of the soil') is referring to the ethnic Malays and several indigenous peoples. 